\title{
The multifaceted role of language in international business: Unpacking the forms, functions and features of a critical challenge to $\mathrm{MNC}$ theory and performance
}

Mary Yoko Brannen ${ }^{1}$, Rebecca Piekkari ${ }^{2}$ and Susanne Tietze ${ }^{3}$

${ }^{1}$ Centre for Asia-Pacific Initiatives, Gustavson School of Business, University of Victoria, BC, Canada; ${ }^{2}$ School of Business, Aalto University, Helsinki, Finland; ${ }^{3}$ Keele University, Staffordshire, UK

\section{Correspondence:}

Mary Y. Brannen

Centre for Asia-Pacific Initiatives,

The University of Victoria, Sedgewick,

C128, Canada.

Tel: +33(0)160 724181;

Fax: +33(0) $160745500 / 01$;

email: maryyoko@uvic.ca

\begin{abstract}
Language lies at the heart of international business (IB) activities, yet language as a key construct in the field of IB has not been sufficiently articulated or theorized. Language presents itself in forms such as national, corporate, technical or electronic, in functions in terms of defining hierarchies, exercising power or facilitating integration and in features such as the use of mixed syntax or gendermarking. Understanding the complex interplay between the multiple facets of language and how they affect day-to-day operations is becoming increasingly critical to global business effectiveness. The purpose of this special issue is, therefore, to catalyze and set a course for the development of a new domain in IB scholarship originating from an explicit focus on language.

Journal of International Business Studies (2014) 45, 495-507. doi:I0. I057/jibs.2014.24
\end{abstract}

Keywords: language (language design, silent language, translation); global business; lingua franca; language strategy; knowledge transfer

Language lies at the heart of international business (IB) activities. It is a necessary constituent of ongoing sequences of decisions and resource commitments that characterize day-to-day organizational life. Such decision making draws on extensive discussion and debate that is framed, formulated and articulated in language developed and, to a certain extent, shared by corporate, functional and other in-group users. As firms internationalize and enter new markets, whether as "born globals" or more traditionally, they must navigate across countless language boundaries including national languages. Operating internationally means having to interact with transcontinental intermediaries, distinct government agencies and foreign institutions, which reside in different language environments. Yet language as a key construct in the field of IB has not been sufficiently articulated or theorized to reflect the particularity of the field. Forms of language such as national, corporate, technical or electronic, its functions in terms of defining hierarchies, exercising power or facilitating integration, as well as its features such as the use of mixed syntax or gender-marking are emerging as critical phenomena for global business. 
The purpose of this special issue is, therefore, to catalyze and set a course for the development of a new domain that originates from an explicit focus on language and languages. We believe that the field of IB is now sufficiently mature to become more sophisticated in its understanding of the multifaceted role of language in today's global business realities. This domain may draw on fields such as anthropology, communication, linguistics and social psychology to explore the nature and complexities of language in contexts where IB is played out. Such research would thereby go beyond the etic, culturally neutral, outsider view of language to the generation of deep, contextual, emic understandings of language in IB which represent a locally grounded perspective (cf. Pike, 1967).

Whereas the IB field has long recognized the importance of language barriers in firm internationalization and in conducting empirical research, the interplay between languages in the daily activities of international management remains opaque and poses a critical challenge to IB theory and practice (Welch, Welch, \& Piekkari, 2005). Corporate language is built over time around domain-specific usages of words, acronyms and stories that often reflect the industry context and the national language environment in the country of origin (Brannen \& Doz, 2012). While such specialized language is usually clear to insiders, it is not to outsiders who lack the shared experience of the former. Moreover, speakers attach invisible meanings to the information exchanged in English as they draw on the language systems and interpretive frames of their respective mother tongues (Kassis Henderson, 2005). This makes it difficult to achieve purposeful communication and significantly complicates knowledge transfer across distance and differentiated contexts. In semiotic terms, transferring the linguistic signals alone across borders does not ensure that the meaning is transferred as intended (Brannen, 2004). Shifts in meaning occur frequently in international encounters as the linguistic codes sent through electronic media are subject to sensemaking in dispersed cultural contexts.

The widespread use of English as lingua franca in most international organizations has further exacerbated the language conundrum. It gives an illusion that by controlling for national language diversity the transfer of meaning becomes relatively unproblematic. Lingua franca was originally conceived as a neutral form of communication without cultural or political bias. There have also been other lingua franca before English that served to integrate the discourses of distinct domains such as French in diplomacy, German in medicine and Latin in scholarship. However, English, as the official language of several of the world's leading economies including five members of the G-20 and the medium through which MBA programs globally are taught, is far from neutral. Its status adds another layer of complexity and calls for sensitivity when attempting to uncover hegemony, ideology and manipulation of meaning in multilingual situations (Archibugi, 2005; Tietze, 2004, 2008).

It is important to note that the very discipline of IB has grown out of articulation and dialog predominantly in the English language. At the systemic level, the institutional machine of academia in general (international conferences, teaching at the major business schools worldwide and so on) as well as publishing (the field's major journals, text books, practitioner publications) functions in English. Tietze and Dick (2013) take a critical look at the lack of reflexivity in regard to the use of English in IB and international management scholarship. They note that from the perspective of the individual researcher, having English as a second or third language is mostly seen and felt as a handicap, something to be overcome, rather than as a potential resource. In fact, one motivation for writing this introduction is that we as guest editors share the early childhood developmental experiences of growing up bilingual in non-English-speaking environments and believe it is important to note that such backgrounds provide the opportunity for reflection. Experiencing mixed formative linguistic backgrounds, as many people do these days, draws attention, immediately and unavoidably, to foreignness and difference, both of which trigger reflection about points of reference, the relativity of meanings and comparability. In this regard, our own biographies influence the choice of topic for this special issue and inform the conceptualization of organizations as multilingual realities.

In this introduction, in order to help set the course of a new domain, we first define "language" as a multifaceted, multilevel construct for IB research. Here we draw on the contributions made by language-sensitive researchers within as well as outside of the field of IB. We then trace the development of the emergent language stream of research in IB and also integrate highlights from articles in this special issue. In doing so, we underscore theoretical advancements, synthesize the key issues facing the field in terms of understanding the multinational corporation (MNC) as a multilingual meeting 
ground and provide the beginnings of a protocol for conducting language research in IB. We should note, however, that our aim is not to offer an exhaustive coverage of the literature, but rather a more selective review that emphasizes the developments we judge to be most relevant and important. We conclude with an overview of the articles that have arisen out of our call for papers for the special issue.

\section{DEFINING LANGUAGE AS A MULTIFACETED AND MULTILEVEL CONSTRUCT FOR IB RESEARCH}

Disciplines define language in their own distinctive ways. For example, in linguistic anthropology language is considered "a cultural resource" that (re) produces the social world (Duranti, 1997; see also SanAntonio, 1987). Within organization studies, language is generally defined as a communicative system of shared meanings that is central in constructing organizational, social and global realities (Astley \& Zammuto, 1992; Daft \& Wiginton, 1979). This echoes speech act theorist Austin's (1962) view that language has "performative power", and thus using language becomes equivalent to "acting in the world". Communication researchers also appreciate language as a constitutive force of organizing (Cooren, Kuhn, Cornelissen, \& Clark, 2011), but they focus primarily on the role of discourse, frames and narratives in sense-making and sensegiving rather than on multiple and different languages per se (see, Logemann, 2013, for an exception).

Likewise, IB scholars share an interest in the performative aspects of language(s) and its role in constituting, enabling and, in some cases, debilitating MNC networks. Embracing different conceptual trajectories to inform their work, IB scholars take diverse approaches to language, reflecting its multifaceted and multilevel nature. Some have begun to engage with the notion of MNC executives using the English language both to create and put into motion hegemonic language strategies (Vaara, Tienari, Piekkari, \& Säntti, 2005). Researchers have also observed the co-existence of English alongside a multitude of other languages in the MNC where their relative order is "linguascaped" in an on-going process of negotiation (Steyaert, Ostendorp, \& Gaibrois, 2011). Others have seen the potential of English as a more neutral communicative tool available for global business (Louhiala-Salminen, Charles, \& Kankaanranta, 2005).

The notion of the common corporate language is a particularly fruitful point of departure in IB as it consists of elements from both specialized and national language - the two facets of language that frequently come up against each other in global business (Fredriksson, Barner-Rasmussen, \& Piekkari, 2006). Corporate language is at once an organizational artifact of how thoughts are formulated as well as how they are communicated and discussed. It becomes important in regards to eliciting employee and investor commitment around strategic initiatives. Carefully word-smithed statements of strategic intent and corporate values in annual reports, internal organizational documents and plasticized pocket-sized value-statement cards are just a few indicators of this. In addition, more and more companies have begun to put in place implicit language guidelines for virtual communication including email, texting, webex and video conferencing in order to avoid misinterpretations. Thus, the language used by decision makers both shapes and bounds what the firm focuses on and how it articulates its strategic options (Brannen \& Doz, 2012). In this special issue, Kuznetsov and Kuznetsova contribute further to this line of research, focusing on the nexus of ties between national language, corporate language (which they term "professional discourse") and the English language. Their decadespanning study shows that a lack of specialized language constitutes a "linguistic hazard" in the context of transformational, post-communist economies which should be included in risk assessment of the MNC.

The analysis of language-in-context has produced typologies of idioms used in the MNC that reflect the inner workings of this organizational form. While Luo and Shenkar (2006) distinguish between parent and subsidiary functional languages, MarschanPiekkari, Welch, and Welch (1999a) refer to parent country, subsidiary and common corporate languages as mentioned above. Moreover, an internal hierarchy of languages has been identified which orders and separates the privileged home country language and the official corporate language from other less prestigious languages employed in the MNC (Marschan-Piekkari et al., 1999a).

In addition to its treatment as an organizationallevel construct, language in IB is researched as an individual- and team-level property in line with the traditions of diversity research (Boxenbaum, 2006). Focusing on the individual level of analysis, Piekkari (2008) treats language as a skill and part of an individual's career capital. Klitmøller (2013) in turn investigates the individual's degree of fluency in the common corporate language of the MNC. 
At the team level of analysis, Brannen, Moore, and, Mughan (2013) show how fluency in English as the corporate language of Tesco plc. and identification with its corporate culture had differential effects on task performance.

In our current special issue, language takes on a variety of distinct focuses, which underscore its multifaceted and multilevel nature. Tenzer, Pudelko and Harzing use language diversity to describe the distribution of differences among the members of a global team, while Hinds, Neeley and Crampton take language in teams a step further by showing how language asymmetries act as a lightning rod which creates faultlines around power and emotions and generates subgroup formation. The team level as an intermediate level of analysis reveals the social character of language and shows how its use is collectively performed with consequences that reach beyond the individual language user. Peltokorpi and Vaara focus on the positive and negative effects of language-sensitive recruitment around proficiency in the lingua franca on knowledge-sharing, while Janssens and Steyaert explore variations on such a language strategy including the possibility of a multilingual franca approach.

In sum, language-sensitive researchers in IB embrace multiple and diverse facets of their subject, reflecting their disciplinary backgrounds as well as their underlying philosophical preferences. A researcher who subscribes to social constructivism views language very differently from someone who is more oriented toward a representationalist or objective language paradigm - the former yielding a more emic analysis, the latter more etic. In this regard, this special issue reflects different research paradigms and approaches, while drawing them together thematically around the topic of language. Given the dominance of quantitative research in IB (Birkinshaw, Brannen, \& Tung, 2011), language has historically been researched from an etic perspective, for example, measuring and quantifying language difference in terms of distance (Dow \& Karunaratna, 2006; West \& Graham, 2004). These contributions have advanced our understanding of language influences from a bird's eye view of macro-organizational outcomes such as trade flows between countries. This special issue takes a more contextually grounded emic approach and strives to provide an "up-close and personal" (Brannen \& Doz, 2010) understanding of the language phenomenon, aiming to capture in situ how language differences shape the lived experience of those who work for today's global organizations.

\section{THE DEVELOPMENT OF "LANGUAGE IN IB" AS A RESEARCH STREAM}

\section{Early Foundations}

The field of IB has addressed the role of language(s) since the 1970s. Research in international marketing and exporting has emphasized the importance of language considerations when selecting foreign markets and selling to overseas customers (Crick, 1999; Hagen, 1999; Holden, 1998; Johanson \& Wiedersheim-Paul, 1975; Leonidou, 1995; MacDonald \& Cook, 1998; Mughan, 1988, 1990; Reeves, 1986; Swift, 1991). Johanson and Wiedersheim-Paul (1975) viewed language as one of the key factors of psychic distance that prevented information about the target market from reaching organizational decision makers (see also Dow \& Karunaratna, 2006). Mughan (1990) showed that British exporters suffered from a loss of business because they were not able to serve their customers in the customer language. These early studies paid attention to the language spoken in the target market when evaluating the attractiveness and accessibility of this market. In the field of industrial marketing and purchasing, suppliers' language skills were seen to influence their ability to establish trustful relationships with foreign buyers (Turnbull \& Cunningham, 1981; Turnbull \& Welham, 1985). In service marketing such as health services (Betancourt, Green, Carrillo, \& Park, 2005) and tourism (Cohen \& Cooper, 1986; Leslie \& Russell, 2006; Martin \& Davies, 2006), linguistically aligned services have been regarded as a means to increase foreign market share and create a source of competitive advantage.

This early work went far in elucidating the critical aspects of language as an important factor in the external environment of the internationalizing firm. However, the fuller theoretical ramifications of the language construct in regards to the internal dayto-day functioning of the global firm had yet to be explored (Holden, 1987). A seminal article by Marschan, Welch, and Welch (1997) entitled "Language: The forgotten factor in multinational management" shifted the focus from thinking of language as a problematic externality to surfacing language issues within the everyday internal contexts of managing the large MNC. Drawing explicit attention to the multilingual reality of MNCs, Marschan et al. (1997) studied subsidiary responses to what they called "language standardization by headquarters", that is, the introduction of a lingua franca such as English as a common corporate 
language. Since then, terms such as anglicization, Englishization (Dor, 2004), Englishnization (Neeley, 2012) and corporate Englishization (Boussebaa et al., 2014) have been proposed to describe how and why English is imposed on managers and employees of the MNC. The decision to mandate a lingua franca such as English is a strong force that shapes organizational processes of inclusion and exclusion. It tends to privilege certain voices and render particular bodies of knowledge more valid than others, which cannot be expressed in English (Welch \& Welch, 2008). This research has led to a more circumspect position toward the role of languages in IB and its influence on global organizational realities.

\section{Recent Developments}

The development of the language stream in IB has taken three formative turns: (1) the decoupling of language from culture, (2) the shift of level of analysis from that of the individual to the organization and (3) the joining together of dispersed studies about language(s) into a recognizable, legitimate field of study in the late 1990s and early years of the millennium. While researchers in other fields such as linguistics (Räisänen, 2013) and sociology (SanAntonio, 1987) have also taken up particular discipline-specific interests in language, what makes the development of this research stream among IB scholars distinct is that it stems from a dual engagement with both the broader business context and the different language environments in which IB activities take place. This in-depth contextual understanding of languages and business provides IB scholars with the resource to be responsive to the new domain.

Let us start from the first formative turn. In IB research, cross-cultural complexity has typically been addressed through a culture lens (Brannen \& Doz, 2010; Hofstede, 1984) where the language construct has been tightly linked to that of national culture (Hofstede, 1986; Kara \& Peterson, 2012). Similarly, scholars in other disciplines have made language central to the way in which nation states are governed and construct their identity (Anderson, 2006; Gellner, 2008). However, as Stahl, Maznevski, Voigt, and Jonsen (2010) showed in their metaanalysis of cultural diversity in teams, there is an important distinction between language-based similarity and similarity originating from a shared national culture (see, also Mäkelä, Kalla, \& Piekkari, 2007). And, as recent work on people with mixed cultural origins has pointed out, bicultural and multicultural does not automatically mean bilingual and multilingual (Brannen \& Thomas, 2010). Thus, while language is clearly related to culture as a concept, the first important step in developing the stream of language in IB has been to disassociate it and study it in its own right (Klitmøller \& Lauring, 2013).

The second development relates to the shift from viewing language exclusively as a skill that resides in the individual to considering it as a constitutive, collective force contained in the MNC. The performative potential of languages to unite, disrupt, form and disable flows of knowledge between different parts and units of the networked MNC began to capture scholarly attention, and IB researchers started to theorize about language as an organizational-level concept (Barner-Rasmussen, 2003; Brannen \& Doz, 2012; Fredriksson et al., 2006; Marschan-Piekkari et al., 1999a). More specifically, IB researchers sought to capture organizational dynamics in multilingual headquarters - subsidiary and inter-subsidiary relationships as well as interorganizational settings such as international joint ventures (Brannen \& Salk, 2000) and mergers and acquisitions (Brannen \& Peterson, 2009; Piekkari, Vaara, Tienari, \& Säntti, 2005; Vaara et al., 2005). Importantly, the consequences of language for individual and organizational identities, for constellations of MNC relationships and the exercise of power were important themes that arose from more recent studies (Vaara et al., 2005).

In the past decade, conceptual contributions also began to emerge which drew heavily on semiotics and translation studies (Brannen, 2004; Janssens, Lambert, $\&$ Steyaert, 2004). Critical contributions used the notion of "linguistic imperialism" to understand how language can be a hegemonic force shaping bodies of knowledge impacting on (management) knowledge workers themselves (Tietze \& Dick, 2013). Thematically, the relationship between the English language as a dominant language over "other" languages has been researched, raising issues of dominance and the hierarchizing of relationships by language ability (Barner-Rasmussen \& Aarnio, 2011; Heikkilä \& Smale, 2011; Steyaert et al., 2011). Most recently, the field has begun to employ cultural and political models of translation to understand the transformation of meaning in global contexts (Janssens et al., 2004; Logemann \& Piekkari, forthcoming; Piekkari, Welch, Welch, Peltonen, \& Vesa, 2013).

Since the late 1990s, the stream of languagesensitive approaches in IB has been growing with increasing alacrity. This growth has been spurred by dedicated conference streams (Academy of International 
Business, 2013; Academy of International Business, 2014; Critical Management Studies, 2007; European Group of Organization Studies, 2010; European Group of Organization Studies, 2013) and special issues of journals (International Studies of Management \& Organization, 2005; Journal of World Business, 2011) which have raised the field's awareness about the existence and influence of languages in internationally operating companies.

Set against this background, the third development was to join the scattered studies undertaken by individual researchers into a recognizable body of language-sensitive perspectives on the operations of the MNC. Scholars on both sides of the Atlantic had investigated language from a variety of perspectives for many years. Researchers based in northern Europe (Andersen \& Rasmussen, 2004; BarnerRasmussen, 2003; Marschan et al., 1997; MarschanPiekkari et al., 1999a, 1999b), the United Kingdom (Holden, 2002, 2008; Feely, 2003) and Australia (Feely \& Harzing, 2003; Harzing \& Feely, 2008; Maclean, 2006; Welch et al., 2005; Welch \& Welch, 2008) started to pull the momentum together into a distinct stream of research in IB. In the United States, Brannen (2004) coined the term "semantic fit" and brought it to bear on the transfer of assets in a multinational context; Luo and Shenkar (2006) put forth the notion of the MNC as a "multilingual community" whose members used a range of languages to interact with each other. Interestingly, the relative elevation of language as a topic of strategic importance was anticipated by Maclean (2006: 1379), who saw the shift in the status of languages "from being both too complex and too simple an issue" to becoming "a question of strategic importance worthy of attention by executives and researchers alike". Yet, as in other streams of research, the work undertaken by US-based researchers, on the one hand, and scholars in Australia and Europe, on the other, largely developed in isolation with limited dialog between the two communities at the time. In this regard, the present special issue further assists in consolidating the growing body of research that has been conducted in various geographical locations and different language environments. Thus, taken together, the above three developments form the foundation of a stream of research which today is known as "language in IB".

\section{Current Issues and Suggested Protocols}

Today, this stream of research has established itself as a legitimate and distinct field of inquiry. First, as a community, it has developed a specialist vocabulary which helps to define the boundaries of the new domain within IB that is distinct from research on related constructs such as culture or communication. For example, instead of focusing on expatriates as cultural boundary spanners, language-sensitive researchers have begun to talk about them as "language nodes" (Marschan-Piekkari et al., 1999b). Alongside notions of social capital, languagesensitive researchers are surfacing the concept of "language capital" (Welch \& Welch, 2008), and next to cultural distance, language-sensitive researchers have begun to theorize and measure "language distance" (West \& Graham, 2004). Further protocols in regards to nomenclature would include researchers paying careful attention to the terms they use to describe in more detail the specific aspects of language they are studying. This could involve distinguishing between national language, corporate language, lingua franca and technical language, for example.

Second, particular methodological challenges associated with multilingual research projects have been articulated. For most IB researchers, fieldwork is not a monolingual experience. Rather, IB research is characterized by linguistic plurality that necessitates ongoing interpretation and translation (Xian, 2008). IB scholars typically collect and analyze data in one or several languages and then write up their findings in yet another language, typically English for publication in English language journals (Welch \& Piekkari, 2006). Survey instruments are constructed in multiple languages, and considerable attention is paid to equivalence of meaning and back translation of research instruments (Green \& White, 1976; Mullen, 1995; Peng, Peterson, \& Shyi, 1991; Usunier, 2011). Language can also act as a type of psychological priming that then affects survey responses (Harzing, 2005). The contribution by Chidlow, Plakoyiannaki, \& Welch (2014) provides a good example of how this work can be taken forward through the development of greater sensitivity to the challenges associated with equivalence and furthering the use of contextsensitive approaches to translation in IB research and scholarship.

Third, related to the above, in IB scholarship, language is rarely tackled systematically as a part of the entire research process. Rather, it is often reduced to a procedural necessity around translating research instruments, interviews or the final research paper itself. In other words, translation is treated as a technicality that accounts for the mechanical process of replacing empirical data expressed in a non-English language with their equivalents in 
English. Yet both theoretical (Janssens et al., 2004; Steyaert \& Janssens, 2013) and empirical accounts (Xian, 2008) point to the transformative power of translation. The act of translating data - whether quantitative or qualitative - is subject to languagerelated decisions, which in turn are influenced by cultural, political and institutional context. The resultant text may therefore be imbued with unintended, and in many cases, equivocal or erroneous meaning (Brannen, 2004). These acts of transformation are rarely made visible and discussed in published work. The contribution by Chidlow et al. (2014) in this issue provides an intellectual trajectory to capture the transformation of data beyond assumptions of equivalence.

Fourth, there are no established protocols for writing up and publishing research projects in English that were originally conceived within non-English research traditions and are based on foreign language data. Some reflective accounts exist in reports on international collaborative research, providing evidence that language and translation matter (Thomas, Tienari, Davies, \& Meriläinen, 2009). They include attending to the multiple languages that researchers bring to bear on the research process from data gathering to interpretation. Ignoring the interplay between languages during the research process may lead to what some have referred to as premature "closure of meaning" (Meriläinen, Tienari, Thomas, \& Davies, 2008: 587), or the silencing of non-English speakers' perspectives and experiences. Going forward, protocols might include a systematic account of how deeply and intensively translators or interpreters have been involved at different stages of the research process, a discussion of problems associated with translating or interpreting particular local expressions or phrases into English and reproduction of some key data in the original local language in the research account. IB journals could be at the forefront in institutionalizing such protocols as best practice.

\section{LOOKING AHEAD}

The alignment of vocabularies and methodological approaches has shaped the identity of this new community of IB researchers and encouraged its members to engage in a dialog with other linguistically infused fields. ${ }^{1}$ In management scholarship, we currently see two distinct communities that have similarly focused on language issues - organization theorists and IB researchers (Janssens et al., 2004). However, to date these two communities exist in parallel. Organization theorists have embraced discourse, rhetoric and narrative analysis and explored themes such as "strategy and strategy making", formation of identity (e.g., gender, postcolonial, professional) as well as organizational and institutional change (Alvesson \& Kärreman, 2000; Knights \& Morgan, 1991; Phillips, Lawrence, \& Hardy, 2004). Despite the undisputable merits of these efforts, from the viewpoint of IB scholarship, a monolingual worldview seems to underlie them, as if day-to-day organizational life would be conducted in one language only English. Steyaert and Janssens (2013) point to the paradox of monolingual scholarship in a multilingual world. For an increasing number of IB researchers, global realities are indeed constructed through a multitude of languages (Piekkari, Welch, \& Welch, 2014; Tietze, 2010). This will be increasingly evidenced with the growing importance of BRIC economies and increasing importance of their languages Spanish, Chinese and Russian.

There are several contributions from our call for papers on language in IB that unite these hitherto separate research communities of organizational theorists and IB researchers and take the first steps toward developing a shared research agenda. Boussebaa et al. apply a postcolonial perspective from organization theory to understand relationships of power and hegemony in global services. Janssens and Steyaert (2014) in this issue develop the notion of the lingua franca and add more differentiation to its multifaceted manifestations including the concept of a multilingual franca. Santacreu-Vasut, Shenkar, and, Shoham (2014) provide an example of how gender as a major research theme in organization theory is highly relevant for the domain of language and languages in IB around comparing the career trajectories of women in countries with languages that do or do not utilize gender-marking.

Another example of shared research interests is encapsulated by the MNC. There is an on-going dialog, perhaps even a debate, between IB scholars and organizational theorists about whether MNCs differ from domestically operating organizations in degree only or also in kind (Ghoshal \& Westney, 1993; Roth \& Kostova, 2003). The argument concerning the degree of difference between these two types of firms is relatively easy to make. The sheer number of countries that an MNC operates in adds to the complexity of the management task. However, the question of whether the MNC differs in kind is harder to answer. Roth and Kostova (2003: 895) explicitly mention language as a trait that renders the MNC conceptually distinct and makes it an attractive research site for theory development. 
As we have discussed, all firms - domestic or otherwise, monolingual or otherwise - operate across diverse language contexts. However, firms in bilingual or multilingual societies such as Canada, Finland or Switzerland often define their identity through their linguistic nature ${ }^{2}$ - either through their bilingualism or multilingualism. Curiously, the MNC does not. Some US firms, in which the official corporate language and the home country language coincide, impose a monolingual Englishonly policy marking their identity (SanAntonio, 1987), and they are met with resistance as a large number of their employees based in non-Englishspeaking countries do not subscribe to what they see as an imposed identity. In other instances, English as the business lingua franca (Louhiala-Salminen et al., 2005) together with the corporate or technical language (Brannen \& Doz, 2012) become unifying codes for the MNC that help navigate the complex language landscape of their geographically dispersed global operations. Thus, in degree, MNCs differ from domestic firms in terms of the diversity of language frontiers they have to cross and manage on a daily basis. In kind, they differ in terms of the nature and influence of the language resources that MNCs can draw on in their day-to-day operations.

Taking further stock of the research to date on language in MNCs, IB scholars have rarely explored the impact of language on organization-based performance directly. Instead, they have made explicit the indirect link between language diversity, management processes and MNC performance. In their conceptual article, Luo and Shenkar (2006: 324) write that "[g]lobal language design affects corporate performance via several channels" such as communication, coordination, knowledge sharing and value creation. Previous empirical findings show that the adoption of a common corporate language changes headquarters-subsidiary relationships (Marschan-Piekkari et al., 1999a), affects cohesion within the MNC (Barner-Rasmussen \& Björkman, 2007) and affects the ability of the MNC to exercise control over its foreign subsidiaries located in different language environments (Björkman \& Piekkari, 2009). Unlike diversity research, where the focus of the extant research has been on the diversityperformance link (Stahl et al., 2010), IB researchers have primarily devoted their attention to the "intervening variables" and processes between language as an input and performance as an output.

The challenge of capturing language implications for individual-based or organizational-based performance offers the opportunity to engage in interdisciplinary blending and scholarship. Experimental studies in cross-cultural psychology, for example, suggest that cognitive processes such as judgment and decision making are affected when an individual uses a foreign language that she/he has not mastered well (Keysar, Hayakawa, \& An, 2012; Takano \& Noda, 1993). In such situations an individual's ability to process thoughts in a logical, sequential manner may temporarily decline (Takano \& Noda, 1993), and decision biases are reduced (Keysar et al., 2012). Keysar et al. (2012) argue that decision makers are able to emotionally distance themselves from the issue at hand when they use a foreign language and, therefore, the effect of framing manipulation disappears. A study on the decision making of Dutch students, for example, demonstrates that when students make decisions "in English" they also identify with aspects of Anglophone culture such as masculinity, performance and assertiveness (Akkermans, Harzing, \& Van Witteloostuijn, 2010).

Extrapolating the findings and logics of these papers, there are potential implications for many decision-making bodies in MNCs. For example, corporate boards are "talking" in one language (frequently English) but "thinking" in another, which may well affect how problems get framed in the first instance and, consequently, how decisions are made. Many Swedish, Norwegian, Finnish and Danish MNCs have changed the working language of their corporate boards from a national Nordic language to English after the entry of the first foreign board member. There is evidence of what Piekkari, Oxelheim and, Randøy (2013) call "the silent boards" in which the introduction of English impoverishes the quality of discussions in board meetings. One can speculate how the language change, at least initially, influences board effectiveness and company performance.

Despite these efforts and contributions, the multiple forms, functions and features of language in MNCs have so far not been fully appreciated or researched. This special issue goes far in extending the existing body of research on language in providing papers that advance the state of the art with methodological innovations, new theoretical ideas and research questions. While some of the articles make novel contributions through interdisciplinary pollination, others take up well-established IB phenomena and re-examine current IB models and frameworks through a language lens, and others offer a re-engagement of IB scholars with methodological issues involving language that goes beyond translation and back-translation of research 
instruments. In addition to educating the understanding of language in IB, we hope that our special issue will catalyze a more reflexive reporting and discussion of these methodological issues and open new horizons for theorizing in future IB research.

\section{OVERVIEW OF THE SPECIAL ISSUE}

Our call for papers generated 78 submissions. This, in and of itself, is a testament to the growing interest in the multifaceted conceptualization of language in the field of IB. Out of these submissions a total of 12 articles were accepted for publication in JIBS by the time we had to go to print. Due to page limit constraints, only six out of these accepted papers are included herein, and the remaining articles are slated for publication in forthcoming issues (and at the time of going to press five of these are already available on the Advance Online Publication section of the JIBS website). In total, these 12 papers cover a wide range of aspects of language in IB including level of analysis, focal points and theoretical contribution that go far in illuminating the multifaceted role of language that our special issue aims to bring to light and set as the course for a new research domain in IB.

The first two papers focus on language issues as they impact global teams. In "The impact of language barriers on trust formation in multinational teams", Helene Tenzer, Markus Pudelko and Anne-Wil Harzing argue that language barriers produce cognitive and emotional reactions among team members, affecting team members' perceptions of trustworthiness and intentions to trust. Their work draws on 90 interviews with team members, team leaders and senior managers in 15 multinational teams in three German automotive companies. Based on this comparative multiple case study, Tenzer et al. propose language as a distinct dimension of diversity and distinguish between deep-level and surface-level diversity offering propositions and a theoretical model for future testing. They further delineate trust formation as a key team process that has important implications for team efficiency and performance.

In "Language as a lightning rod: Power contests, emotion regulation, and subgroup dynamics in global teams" using qualitative methodology, Pamela Hinds, Tsedal Neeley and Catherine Cramton induce a model that captures how asymmetries in language fluency contribute to an "us vs them" dynamic that often transpires in global teams. Their findings extend IB theory on subgroup dynamics in global teams by adding language as a potential faultline, showing how power struggles activate such faulti- ness and are in turn reinforced. They also document the emotion regulation processes triggered by subgrouping and enacted through language-related choices and behaviors.

In the third paper, "Translation in cross-language international business research: Beyond equivalence", Agnieszka Chidlow, Emmanuella Plakoyiannaki and Catherine Welch analyze cross-language studies published in four key IB journals (International Business Review, Journal of International Business Studies, Journal of World Business, Management International Review). The authors demonstrate that the overall approach taken by IB scholars is based on a technicist view of translation, which assumes that equivalence of meaning between languages exists and that it can be accounted for in research studies by following cursory protocols of back-translation. In contrast, the authors advocate a turn to contextualized translation theories, viz. skopos theory and cultural politics, to inform future cross-language IB research as based on explicit acknowledgment and treatment of translation as social practice. Thus, translation itself can be treated as data and as a source of contextual insights and conceptual understanding.

In "Building professional discourse in emerging markets: Language, context and the challenge of sensemaking", Andrei Kuznetsov and Olga Kuznetsova focus on the notion of professional discourse among business and management practitioners and academics and investigates the consequences if such professional discourse is lacking or underdeveloped. Located in several former post-communist Soviet economies, the retrospective-observational study employs a sense-making framework and shows that a lack of a professional language leads to "communicative disengagement", which increases the "liability of foreignness" - the additional cost or risk a firm operating in nondomestic market incurs. The authors propose that the lack of professional discourse constitutes a linguistic hazard for a foreign firm and that it should be factored into business strategies of MNCs. The use of English as lingua franca does not fully resolve the lack of professional discourse, as it cannot compensate for the constrained terminological capacity of the native professional language.

In "Knowledge transfer in multinational corporations: Productive and counterproductive effects of language-sensitive recruitment", Vesa Peltokorpi and Eero Vaara focus on the productive and counterproductive effects of language-sensitive recruitment on knowledge transfer in MNCs. To examine these effects, the authors used a mixed method 
triangulation, first deploying qualitative case studies of 101 foreign subsidiaries to inductively develop a model on the communication competence, network, identity and power-related effects of language-sensitive recruitment. Then they utilized survey data to validate the results of the qualitative analysis. The findings show an inverted U-shaped relationship between language-sensitive recruiting and knowledge transfer.

In "Re-Considering Language Within A Cosmopolitan Understanding: Towards A Multilingual Franca Approach In International Business Studies", Maddy Janssens and Chris Steyaert apply sociolinguistics and cosmopolitan theory to conceive language as a social practice and posit globalization as the entanglement between universality and particularity in linguistic traditions. Combining these linguistic and global assumptions, the authors offer a nuanced understanding of the various approaches to lingua franca in MNCs global work settings: monological lingua franca, monological multilingualism, and multilingual franca. As the latter approach is unexplored, the authors contribute strongly to the IB field offering a novel option to the challenge of managing languages in an international business.

In addition to the six articles included in this issue, the following forthcoming papers have been accepted at JIBS as a result of our call for papers on language in IB: "Englishization in offshore call centres: A postcolonial perspective," by Mehdi Boussebaa, Sinha Shuchi and Gabriel Yiannis, "A more expansive perspective on translation in IB research: Insights from the Russian Handbook of Knowledge Management", by Snejina Michailova and Nigel Holden; "Brain drain: The cognitive

\section{REFERENCES}

Akkermans, D., Harzing, A. -W., \& Van Witteloostuijn, A. 2010. Cultural accommodation and language priming: Competitive versus cooperative behavior in a prisoner dilemma game. Management International Review, 50(5): 559-583.

Alvesson, M., \& Kärreman, D. 2000. Varieties of discourse: On the study of organizations through discourse analysis. Human Relations, 53(9): 1125-1149.

Andersen, H., \& Rasmussen, E. S. 2004. The role of language skills in corporate communication. Corporate Communications: An International Journal, 9(2): 231-242.

Anderson, B. 2006. Imagined communities: Reflections on the origin and spread of nationalism. London: Verso.

Archibugi, D. 2005. The language of democracy: Vernacular or Esperanto? A comparison between the multiculturalist and cosmopolitan perspectives. Political Studies, 53(3): 537-555.

Astley, W. G., \& Zammuto, R. F. 1992. Organization science, managers, and language games. Organization Science, 3(4): 443-460.

Austin, J. L. 1962. How to do things with words. Cambridge, MA: Harvard Business School. neuroscience of foreign language processing in multinational corporations", by Stefan Volk, Tine Köhler and Markus Pudelko; "Linguistic gender marking and its international business ramifications", by Estefania Santacreu-Vasut, Oded Shenkar and Amir Shoham; "Cultural and language skills as resources for boundary spanning within the MNC", by Wilhelm Barner-Rasmussen, Mats Ehrnrooth, Alexei Koveshnikov and Kristiina Mäkelä; and "How non-native English speaking staff are evaluated in linguistically diverse organizations: A sociolinguistic perspective", by Marjana Johansson and Martyna Śliwa.

\section{ACKNOWLEDGEMENTS}

We would like to acknowledge our three anonymous reviewers, and the EIC, John Cantwell, for their helpful comments on earlier drafts of this introduction. We also thank Bea Alanko of the Aalto University for help in formatting and finalizing the manuscript. Final thanks go to Trixie Brannen for patiently standing by while this Special Issue was put to bed.

\section{NOTES}

${ }^{1}$ Rorty (1992) has termed this phenomenon in which diverse disciplines began taking up language as a central construct a linguistic turn in the evolution of theory development in a field of research.

${ }^{2}$ We owe this insight to Eleanor Westney (personal communication, 25 October 2013). The linking of language to national identity has been made in multiple disciplines - cf. noted work by Anderson (2006) in anthropology, Gellner (2008) in political science and Babha (1990) in literary criticism.

Barner-Rasmussen, W. 2003. Knowledge sharing in multinational corporations: A social capital perspective. PhD Dissertation, Swedish School of Economics and Business Administration, Helsinki, Finland.

Barner-Rasmussen, W., \& Aarnio, C. 2011. Shifting the faultlines of language: A quantitative functional-level exploration of language use in MNC subsidiaries. Journal of World Business, 46(3): 288-295.

Barner-Rasmussen, W., \& Björkman, I. 2007. Language fluency, socialization and inter-unit relationships in Chinese and Finnish subsidiaries. Management and Organization Review, 3(1): 105-128.

Betancourt, J. R., Green, A. R., Carrillo, J. E., \& Park, E. R. 2005. Cultural competence and health care disparities: Key perspectives and trends. Health Affairs, 24(2): 499-505.

Bhabha, H. 1990. DissemiNation: Time, narrative, and the margins of the modern nation. New York: Routledge.

Birkinshaw, J., Brannen, M. Y., \& Tung, R. 2011. From a distance and generalizable to up close and grounded: Reclaiming a 
place for qualitative methods in international business research. Journal of International Business Studies, 42(5): 573-581.

Björkman, A., \& Piekkari, R. 2009. Language and foreign subsidiary control: An empirical test. Journal of International Management, 15(1): 105-117.

Boussebaa, M., Sinha, S., \& Gabriel, Y. 2014. Englishization in offshore call centers: A postcolonial perspective. Journal of International Business Studies, advance online publication 22 May. doi:10.1057/jibs.2014.25.

Boxenbaum, E. 2006. Lost in translation: The making of Danish diversity management. American Behavioral Scientist, 49(7): 939-948.

Brannen, M. Y. 2004. When Mickey loses face: Recontextualization, semantic fit and the semiotics of foreignness. Academy of Management Review, 29(4): 593-616.

Brannen, M. Y., \& Doz, Y. L. 2010. From a distance and detached to up close and personal: Bridging strategic and cross-cultural perspectives in international management research and practice. Scandinavian Journal of Management, 26(3): 236-247.

Brannen, M. Y., \& Doz, Y. L. 2012. Corporate languages and strategic agility: Trapped in your jargon or lost in translation? California Management Review, 54(3): 77-97.

Brannen, M. Y., \& Peterson, M. F. 2009. Merging without alienating: Interventions promoting cross-cultural organizational integration and their limitations. Journal of International Business Studies, 40(3): 468-489.

Brannen, M. Y., \& Salk, J. E. 2000. Partnering across borders: Negotiating organizational culture in a German-Japanese joint venture. Human Relations, 53(4): 451-487.

Brannen, M. Y., \& Thomas, D. C. 2010. Bicultural individuals in organizations: Implications and opportunity. International Journal of Cross Cultural Management, 10(1): 5-16.

Brannen, M. Y., Moore, F., \& Mughan, T. 2013. Strategic ethnography and reinvigorating Tesco Plc: Leveraging inside/ out bicultural bridging in multicultural teams. In EPIC 2013 London. Proceedings of the Ethnographic Praxis in Industry Conference; 15-18 September, London, 255-272. Arlington, VA: American anthropological Association.

Chidlow, A., Plakoyiannaki, E., \& Welch, C. 2014. Translation in cross-language international business research: Beyond equivalence. Journal of International Business Studies, 45(5): 562-582.

Cohen, E., \& Cooper, R. L. 1986. Language and tourism. Annals of Tourisms Research, 13(4): 533-563.

Cooren, F., Kuhn, T., Cornelissen, J. P., \& Clark, T. 2011. Communication, organizing and organization: An overview and introduction to the special issue. Organization Studies, 32(9): 1149-1170.

Crick, D. 1999. An investigation into SMEs' use of languages in their export operations. International Journal of Entrepreneurial Behaviour and Research, 5(1): 19-31.

Daft, R. L., \& Wiginton, J. C. 1979. Language and organization. Academy of Management Review, 4(2): 179-191.

Dor, D. 2004. From Englishization to imposed multilingualism: Globalization, the internet and the political economy on the linguistic code. Public Culture, 16(1): 97-118.

Dow, D., \& Karunaratna, A. 2006. Developing a multidimensional instrument to measure psychic distance stimuli. Journal of International Business Studies, 37(5): 578-602.

Duranti, A. 1997. Linguistic anthropology. Cambridge: Cambridge University Press.

Feely, A. J. 2003. Communication across language boundaries. In M. Tayeb (Ed), International management: Theories and practices: 206-235. London: Pearson Education.

Feely, A. J., \& Harzing, A. -W. 2003. Language management in multinational companies. Cross-Cultural Management: An International Journal, 10(2): 37-52.

Fredriksson, R., Barner-Rasmussen, W., \& Piekkari, R. 2006. The multinational corporation as a multilingual organization: The notion of a common corporate language. Corporate Communications: An International Journal, 11(4): 406-423.

Gellner, E. 2008. Nations and nationalism. Ithaca, NY: Cornell University Press.
Ghoshal, S., \& Westney, D. E. 1993. Organizational theory and the multinational. London: Palgrave Macmillan.

Green, R. T., \& White, P. D. 1976. Methodological considerations in cross-national consumer research. Journal of International Business Studies, 10(2): 81-87.

Hagen, S. 1999. Business communication across borders. A study of language use and practice in European countries. Stirling: CILT/ Languages NTQ.

Harzing, A.-W. 2005. Does the use of English-language questionnaires in cross-national research obscure national differences? International Journal of Cross-Cultural Management, 5(2): 213-224.

Harzing, A. -W., \& Feely, A. J. 2008. The language barrier and its implications for HQ-subsidiary relationships. Cross Cultural Management: An International Journal, 15(1): 49-60.

Heikkilä, J.-P., \& Smale, A. 2011. The effects of "language standardization" on the acceptance and use of e-HRM systems in foreign subsidiaries. Journal of World Business, 4(3): 305-313.

Hofstede, G. 1984. Culture's consequences: International differences in work-related values. London: Sage.

Hofstede, G. 1986. Cultural differences in teaching and learning. International Journal of Intercultural Relations, 10(3): $301-320$.

Holden, N. 1987. The treatment of language and linguistic issues in the current English-language international management literature. Multilingua, 6(3): 233-246.

Holden, N. 1998. International marketing studies: Time to break the English strangle-hold? International Marketing Review, 15(2): 86-100.

Holden, N. 2002. Cross-cultural management: A knowledge management perspective. Harlow: Pearson Education.

Holden, N. J. 2008. Reflections of a cross-cultural scholar: Context and language in management thought. International journal of Cross Cultural Management, 8(2): 239-250.

Janssens, M., \& Steyaert, C. 2014. Re-considering language within a cosmopolitan understanding: Toward a multilingual franca approach in international business studies. Journal of International Business Studies, 45(5): 623-639.

Janssens, M., Lambert, J., \& Steyaert, C. 2004. Developing language strategies for international companies: The contribution of translation studies. Journal of World Business, 39(4): 414-430.

Johanson, J., \& Wiedersheim-Paul, F. 1975. The internationalization of the firm - Four Swedish cases. Journal of Management Studies, 12(3): 305-322.

Kara, A., \& Peterson, M. F. 2012. The dynamic societal cultural milieu of organizations: Origins, maintenance and change. Advances in International Management, 25: 341-371.

Kassis Henderson, J. 2005. Language diversity in international management teams. International Studies of Organization \& Management, 35(2): 66-82.

Keysar, B., Hayakawa, S. L., \& An, S. G. 2012. The foreignlanguage effect: Thinking in a foreign tongue reduces decision biases. Psychological Science, 23(6): 661-668.

Klitmøller, A. 2013. (Re)contextualizing cultural and linguistic boundaries in multinational corporations: A global ethnographic approach. PhD Dissertation, Aarhus University, Aarhus, Denmark.

Klitmøller, A., \& Lauring, J. 2013. When global virtual teams share knowledge: Media richness, cultural difference and language commonality. Journal of World Business, 48(3): 398-406.

Knights, D., \& Morgan, G. 1991. Corporate strategy, organizations, and subjectivity: A critique. Organization Studies, 12(2): 251-273.

Leonidou, L. C. 1995. Empirical research on export barriers: Review, assessment, and synthesis. Journal of International Marketing, 3(1): 29-43.

Leslie, D., \& Russell, H. 2006. The importance of foreign language skills in the tourism sector: A comparative study of student 
perceptions in the UK and continental Europe. Tourism Management, 27(6): 1397-1407.

Logemann, M. 2013. Strategic change under construction: Role of strategy narratives. PhD Dissertation, School of Business, Aalto University, Helsinki, Finland.

Logemann, M., \& Piekkari, R. forthcoming. Localise or local lies? The power of language and translation in the MNC. Critical Perspectives on International Business, accepted.

Louhiala-Salminen, L., Charles, M., \& Kankaanranta, A. 2005. English as a lingua franca in Nordic corporate mergers: Two case companies. English for Specific Purposes, 24(4): 401-421.

Luo, Y., \& Shenkar, O. 2006. The multinational corporation as a multilingual community: Language and organization in a global context. Journal of International Business Studies, 37(3): 321-339.

MacDonald, S., \& Cook, M. 1998. An exploration of the use of language training in exporting firms. Case studies from Northamptonshire. Local Economy, 13(3): 216-227.

Maclean, D. 2006. Beyond English: Transnational corporations and the strategic management of language in a complex multilingual business environment. Management Decision, 44(10): 1377-1390.

Marschan, R., Welch, D., \& Welch, L. 1997. Language: The forgotten factor in multinational management. European Management Journal, 15(5): 591-598.

Marschan-Piekkari, R., Welch, D. E., \& Welch, L. S. 1999a. In the shadow: The impact of language on structure, power and communication in the multinational. International Business Review, 8(4): 421-440.

Marschan-Piekkari, R., Welch, D. E., \& Welch, L. S. 1999b. Adopting a common corporate language: IHRM implications. International Journal of Human Resource Management, 10(3): 377-390.

Martin, A., \& Davies, S. 2006. An evaluation of the language skills in Scottish hotels. Journal of Hospitality, Leisure, Sport and Tourism Education, 5(1): 4-15.

Meriläinen, S., Tienari, J., Thomas, R., \& Davies, T. 2008. Hegemonic academic practices: Experiences of publishing from the periphery. Organization, 15(4): 584-597.

Mughan, T. 1988. Why British firms must break through the language barrier. The Times, 17 September.

Mughan, T. 1990. Is "languages for export" enough? European Business Review, 90(3): 22-25.

Mullen, M. R. 1995. Diagnosing measurement equivalence in cross-national research. Journal of International Business Studies, 26(3): 573-596.

Mäkelä, K., Kalla, H., \& Piekkari, R. 2007. Interpersonal similarity as a driver for knowledge sharing within multinational corporations. International Business Review, 16(1): 1-22.

Neeley, T. 2012. Global business speaks English. Harvard Business Review, 90(5): 116-124.

Peng, T. K., Peterson, M. F., \& Shyi, Y. -P. 1991. Quantitative methods in cross-national management research: Trends and equivalence issues. Journal of Organizational Behavior, 12(2): 87-107.

Phillips, N., Lawrence, T., \& Hardy, C. 2004. Discourse and institutions. Academy of Management Review, 29(4): 635-652.

Piekkari, R. 2008. Languages and careers in multinational corporations. In S. Tietze (Ed), International management and language 128-137. London: Routledge.

Piekkari, R., Oxelheim, L., \& Randøy, T. 2013. The role of language in corporate governance: The case of board internationalization. IFN Working Paper no. 974, Research Institute of Industrial Economics, Stockholm.

Piekkari, R., Vaara, E., Tienari, J., \& Säntti, R. 2005. Integration or disintegration? Human resource implications of a common corporate language decision in a cross-border merger. International Journal of Human Resource Management, 16(3): 333-347.

Piekkari, R., Welch, D. E., \& Welch, L. S. 2014. Language in international business: The multilingual reality of global business expansion. Cheltenham: Edward Elgar.
Piekkari, R., Welch, D. E., Welch, L. S., Peltonen, J. -P., \& Vesa, T. 2013. Translation behavior: An exploratory study within a service multinational. International Business Review, 22(5): 771-783.

Pike, K. L. 1967. Etic and emic standpoints for the description of behavior. In D. C. Hildum (Ed), Language and thought: An enduring problem in psychology: 32-39. Princeton, NJ: D. Van Norstrand Company.

Reeves, N. 1986. Education for exporting capability: Languages and market penetration. Journal of the Royal Society of Arts, 134(5355): 182-197.

Rorty, R. (Ed) 1992. The linguistic turn: Essays in philosophical method. Chicago: University of Chicago Press.

Roth, K., \& Kostova, T. 2003. The use of the multinational corporation as a research context. Journal of Management, 29(6): 883-902.

Räisänen, T. 2013. Professional communicative repertoires and trajectories of socialization into global working life. PhD Dissertation, University of Jyväskylä, Jyväskylä, Finland.

SanAntonio, P. M. 1987. Social mobility and language use in an American company in Japan. Journal of Language and Social Psychology, 6(3-4): 191-200.

Santacreu-Vasut, E., Shenkar, O., \& Shoham, A. 2014. Linguistic gender marking and its international business ramifications. Journal of International Business Studies, advance online publication 20 February, doi:10.1057/jibs.2014.5.

Stahl, G. K., Maznevski, M. L., Voigt, A., \& Jonsen, K. 2010. Unraveling the effects of cultural diversity in teams: A metaanalysis of research on multicultural work groups. Journal of International Business Studies, 41(4): 690-709.

Steyaert, C., \& Janssens, M. 2013. Multilingual scholarship and the paradox of translating and language in management and organization studies. Organization, 20(1): 131-142.

Steyaert, C., Ostendorp, A., \& Gaibrois, C. 2011. Multilingual organizations as "linguascapes": Negotiating the position of English through discursive practices. Journal of World Business, 46(3): 270-278.

Swift, J. S. 1991. Foreign language ability and international marketing. European Journal of Marketing, 25(12): 36-49.

Takano, Y., \& Noda, A. 1993. A temporary decline of thinking ability during foreign language processing. Journal of CrossCultural Psychology, 24(4): 445-462.

Thomas, R., Tienari, J., Davies, A., \& Meriläinen, S. 2009. Let's talk about "us": A reflexive account of a cross-cultural research collaboration. Journal of Management Inquiry, 18(4): 313-324.

Tietze, S. 2004. Spreading the management gospel - in English. Language and Intercultural Communication, 4(3): 175-189.

Tietze, S. 2008. International management and language. London: Routledge.

Tietze, S. 2010. International managers as translators. European Journal of International Management, 4(1-2): 184-199.

Tietze, S., \& Dick, P. 2013. The victorious English language: Hegemonic practices in the management academy. Journal of Management Inquiry, 22(1): 122-134.

Turnbull, P., \& Cunningham, M. T. 1981. International marketing and purchasing: A survey among marketing and purchasing in five European countries. London: Palgrave Macmillan.

Turnbull, P., \& Welham, G. F. 1985. The characteristics of European export marketing staff. European Journal of Marketing, 19(2): 31-41

Usunier, J. -C. 2011. Language as a resource to assess crosscultural equivalence in quantitative management research. Journal of World Business, 46(3): 314-319.

Vaara, E., Tienari, J., Piekkari, R., \& Säntti, R. 2005. Language and the circuits of power in a merging multinational corporation. Journal of Management Studies, 42(3): 595-623.

Welch, C., \& Piekkari, R. 2006. Crossing language boundaries: Qualitative interviewing in international business. Management International Review, 46(4): 417-437.

Welch, D. E., \& Welch, L. S. 2008. The importance of language in international knowledge transfer. Management International Review, 48(3): 339-360 
Welch, D. E., Welch, L. S., \& Piekkari, R. 2005. Speaking in tongues: The importance of language in international management processes. International Studies of Management \& Organization, 35(1): 10-27.

West, J., \& Graham, J. L. 2004. A linguistic-based measure of cultural distance and its relationship to managerial values. Management International Review, 44(3): 239-260.

Xian, H. 2008. Lost in translation? Language, culture and the roles of translator in cross-cultural management research. Qualitative Research in Organizations and Management: An International Journal, 3(3): 231-245.

\section{ABOUT THE AUTHORS}

Mary Yoko Brannen is Professor of International Business at the Peter B. Gustavson School of Business and holds the Jarislowsky East Asia (Japan) Chair at the Centre for Asia-Pacific Initiatives at the University of Victoria. Her research focuses on knowledge sharing, multinational integration and understanding boundary-spanning capabilities of people with multicultural identities. She is Deputy Editor of JIBS and has published in such journals as the Academy of Management Review, Academy of Management Journal, Human Relations, Journal of Management Inquiry and the Anthropology of Work Review.
Rebecca Piekkari is Professor of International Business at Aalto University, School of Business in Finland. Her research focuses on language in international business and the use of qualitative methods in management and organizational research. She has also participated in the discussion about language as a methodological question. Her work has been published in journals such as the Academy of Management Review, Journal of Management Studies and Journal of International Business Studies, as well as in several handbooks in the area.

Susanne Tietze is Professor of Management at Keele University, Keele Management School, UK. Using an interpretive approach her research has focused on flexible working practices, gender, identity, culture, languages, discourse and communication in organizational settings. Current research projects are exploring the agentic role of the translator in knowledge translation between different localities. Her work has been published in journals such as Organization Studies, Journal of Management Studies, International Journal of Human Resource Management, and Journal of Business Ethics. 